\title{
NECDUM ORBEM MEDIUM: NIGHT IN THE AENEID
}

Summary: The appearances of the goddess Night in Virgil's Aeneid can be profitably studied as a cipher to appreciating better certain key elements of the poet's epic presentation of Troy's fall and the rise of the future Rome. Detailed consideration of every epiphany of the goddess in the poem offers insight into Virgil's rationale for how he presents the ultimate resolution of the conflict in Latium and the quelling of Juno's rage against the Trojans.

Key words: Night, Hours, Aeneas, Turnus, Palinurus, Troy, Rome, Juno, Dira, Furies

The appearances of the goddess Night in Virgil's Aeneid have not been studied with particular attention. ${ }^{1}$ The present investigation will consider all the scenes in the epic in which Night plays a role, with a focus on explicating how Virgil employs the seemingly obscure and minor immortal as a key figure in the unfolding of his poetic vision of the fall of Troy and the rise of Rome. ${ }^{2}$ We shall see that Virgil carefully arranges his references to the goddess Nox in ordered progression through the course of the epic, and that the immortal of the night plays a significant role in the ultimate resolution of the conflict of the war in Latium - and, not least, in the surrender of the fury and madness of Juno to the Trojan Aeneas.

${ }^{1}$ See especially BAgNOLINI, A.: Nox. In Enciclopedia virgiliana (hereafter EV) III 770-772 (with illustration); and FratANTUONO, L. - THOMAS, R.: Night in The Virgil Encyclopedia (hereafter VE) II 904-905. On the Furies (the daughters of Night), see LowE, D.: Monsters and Monstrosity in Augustan Poetry. Ann Arbor 2015, 146ff. I am grateful to the editor, and to the comments of the anonymous referee that much improved this study.

2 Our study is limited to references to the goddess, not to every one of the many Noctes Vergilianae; for the shading of the mythological and the allegorical in the Virgilian depictions of Nox, see BAILEY, C.: Religion in Virgil. Oxford 1935, 185-187: "These cosmological deities, then, with the possible exceptions of Sol and Nox, have very little religious significance and are either mythological inheritances from the Greek or faint personifications of natural phenomena." 
Night makes her first epiphany in the Aeneid at a dramatic moment: the eve of the first Trojan landing on Italian soil. ${ }^{3}$ It was not yet midnight when Aeneas' helmsman Palinurus rose from sleep to check the stars and to make the decision for the Trojans to leave southern Albania for Italy by the shortest route across the Adriatic:

Provehimur pelago vicina Ceraunia iuxta, unde iter Italiam cursusque brevissimus undis.

sol ruit interea et montes umbrantur opaci; sternimur optatae gremio telluris ad undam sortiti remos passimque in litore sicco

corpora curamus, fessos sopor inrigat artus. necdum orbem medium Nox Horis acta subibat:

haud segnis strato surgit Palinurus et omnis

explorat ventos atque auribus aëra captat;

sidera cuncta notat tacito labentia caelo,

Arcturum pluviasque Hyadas geminosque Triones,

Armatumque auro circumspicit Oriona.

postquam cuncta videt caelo constare sereno,

dat clarum e puppi signum; nos castra movemus

temptamusque viam et velorum pandimus alas.

III 506-520

The scene offers the first of eight named epiphanies of the goddess Night in the epic. ${ }^{5}$ In this case, the night is of signal importance in the ongoing journey of the Trojan exiles to their destined western homecoming; Dawn and morning will find Aeneas and his men at Castrum Minervae and the first landing in Italy (III 521ff.). ${ }^{6}$ Aurora is the goddess who presides over the arrival in Hesperia (III 521); Night is the patroness of the journey. We shall be reminded soon enough that she is also the mother of the Furies - and fittingly so, given that arrival in Italy will spell war. ${ }^{7}$ The resolution of that war will bring with it the settlement of how Trojans and Latins are to coexist in Italy; the war will end on the mortal level with the defeat and death of Turnus, while on the divine plane it will close with the reconciliation of Juno.

The briefly yet memorably sketched nocturnal sequence affords a brief and telling glimpse into the life of the weary travelers. Palinurus is able to snatch some

3 "Nox" is capitalized in the corrected edition of Mynors' Oxford text at III 512. Both Geymonat and Conte also accept the personification, which is ultimately a matter of editorial discretion. Here the reference seems to be to the goddess, driven as she is by her chariot of the Hours (III 512 acta Horis, with which cf. V 721; on the question of the personification of the Hours, see the recent remarks of Heyworth and Morwood in their 2017 Oxford edition of Book III). We may compare the extended description of the night at II 250ff., in the prelude to the dream epiphany of Hector, where Mynors, Geymonat, Conte (et al.) do not see a personification (though Heuzé's Pléiade edition does). Night (whether personified or not) is of course intimately associated with the fall of Troy. The nox of II 360 should likely not be capitalized.

${ }^{4}$ All quotes from Virgil are taken from MYNORS, R. A. B.: P. Vergili Maronis Opera Omnia. Oxford 1969 (corrected reprint 1972).

${ }^{5}$ The goddess is referred to periphrastically at VI 250.

${ }^{6}$ For the exact itinerary and landing place, see HoRSFALL, N.: Virgil, Aeneid. Leiden-Boston 2006, ad 531-536; cf. SAUNDERS, C.: Vergil's Primitive Italy. Oxford University Press 1930, 7-9.

${ }^{7} \mathrm{Cf}$. the predictions of war that follow on the portent of the four horses of war. 
brief moments of no doubt much needed slumber; the dutiful helmsman can be expected to find sleep difficult on ship - and even on the strand, he is the first to break his rest and to observe the heavens. ${ }^{8}$ Appropriately enough, the helmsman observes the stars carefully in anticipation of the voyage; the Virgilian commentators have pursued the astronomical implications of the poet's description with perhaps even more assiduous care and attention. ${ }^{9}$

It was not yet midnight when Palinurus rose from sleep (III 512). With this detail about the middle of the night - more precisely, the time just before the midpoint of Night's course as she is driven by the Hours ${ }^{10}$ - we might compare VI 536ff., where the poet observes that the Dawn had just passed the medium axem of her journey across the sky, and where in consequence of the hour the Sibyl urges Aeneas to advance past the crucial parting of the ways between Tartarus and Elysium - since night was rushing on (VI 539 nox ruit). ${ }^{11}$ The time is rather the reverse of the Palinuran passage; the helmsman rose in the night to essay his journey just before the midnight hour, while in the underworld we are reminded that it is just after noon, and the night is drawing ever nearer. In conjunction with both passages is the high noon (or just after) of VIII 97 sol medium caeli conscenderat igneus orbem, as Aeneas first glimpses the humble abode of Evander and Pallas - the future sight of Romana potentia (VIII 99). ${ }^{12}$

The only references to the orbis medius in the Aeneid come, then, just as Palinurus makes ready for the first landing in Italy, and as Aeneas sees the destined locale of Roman power; both passages are in close proximity, too, to celebrated omens. ${ }^{13}$ It was not yet midnight when Palinurus checked the stars for the first Trojan arrival in Italy; three of the four astronomical markers that are mentioned (the Hyades, Arcturus, and Orion) are associated with bad weather and tempest. ${ }^{14}$ Despite the baleful starry warnings, the sky is quite calm for the journey. ${ }^{15}$ And with the dawn, rejoicing: the Trojans will land in Italy with the rising of Aurora, and they will see the admit-

${ }^{8}$ Haud segnis occurs only here in Virgil; the adjective is poetic and not particular common (cf. Georgics I 151; III 42; Aeneid VIII 549; X 308 and 592; XI 21). The emphasis on Palinurus' devotion to his craft serves in part to foreshadow the eerie drama of the close of Book V.

9 "Palinurus' stars have been studied with some energy and to no happy outcome" (HORSFALL [n. 5] ad III 516-517); for detailed analysis and argument in favor of a January departure from Buthrotum, see MANDRA, R.: The Time Element in the Aeneid of Vergil: An Investigation. Williamsport, Pennsylvania $1934,71-76$.

${ }^{10} \mathrm{This}$ is the only appearance of the personified Hours in the epic (but cf. VI 539); for the Horae see BÖMER, F.: P. Ovidius Naso Metamorphosen Buch I-III. Heidelberg 1969, ad II 26. They do not appear frequently in surviving Latin verse.

${ }^{11}$ VI 536 iam medium aetherio cursu traiecerat axem; see here HoRSFALl, N.: Virgil, Aeneid 6. Berlin-Boston 2013, ad loc. This scene occurs after the enounters of Aeneas with the shades of Palinurus et al.

${ }^{12}$ Put another way, it was not yet midnight when Palinurus rose, and it was just after noon when Aeneas and the Sibyl were at the crossroads in the underworld - but it was dawn and high noon when the Trojans landed in Italy, and when Aeneas saw the future site of Roman power.

${ }^{13}$ In the former case, the four horses of war, and in the latter, the sow and her thirty piglets. The one heralds the future war, the other the rule of Iulus at Alba Longa.

${ }^{14} \mathrm{Cf}$. Horsfall (n. 5) ad III 516-517.

15 "In fact P. studies the sky, sees no signs of trouble ... and none will occur, despite all that V. and his sources have read, for this one crucial night." (Horsfall). 
tedly "obscured" hills of Italy. ${ }^{16}$ The hills are obscured in part because of their distance from the coast; ${ }^{17}$ there is also the sense that this is in some ways an abortive landing - the Trojans will not remain in this place that is marked both by the temple of Minerva (III 531) and the portentous horses of war. ${ }^{18}$ Just as other locales are briefly visited and then left behind in the travel narrative of Book III, so Castrum Minervae offers but a brief interlude on the progress of the journey to Latium.

Divine favor may be credited for the safe voyage across the Adriatic. ${ }^{19}$ Still, there are ominous undertones to the passage; ultimately, the portentous appearance of four horses of war is (correctly) interpreted by Anchises to be a harbinger of a future war in Italy. ${ }^{20}$ And, soon enough, the helmsman Palinurus will die - a victim of his second and final landfall in the Italy he now rejoices to see. For now, we see a clear progression from night to morning, as the Trojans almost tentatively prepare to land in Italy; further landings in Book VI and VII will bring them first to the threshold of the underworld, and then at last to the locus of both settlement and war.

The next appearance of Night in the epic comes in a context that is more mysterious and dreamlike than the relatively brief sailing across the Adriatic: the nocturnal apparition of Anchises to his son in Sicily. ${ }^{21}$ It was night when the ghost ${ }^{22}$ of the father appeared to counsel his son on the matter of Nautes' suggestion to leave behind Trojans in Sicily with Acestes; black Night in her two-horse chariot was holding the pole:

\section{Talibus incensus dictis senioris amici \\ tum vero in curas animo diducitur omnis; \\ et Nox atra polum bigis subvecta tenebat. visa dehinc caelo facies delapsa parentis \\ Anchisae subito talis effundere voces:}

V 719-723

Night is now black (V 721 atra); the chromatic detail is grim, and the adjective significant. ${ }^{23}$ Again the time may be just before midnight; in V 721 subvecta we see an image of Night being conveyed upwards in her chariot as she climbs the heaven, that

${ }^{16}$ III 522 cum procul obscuros collis ... videmus.

${ }^{17}$ Cf. Horsfall (n. 5) here ad loc.

${ }^{18}$ Castrum Minervae, with its temple to the goddess and equestrian omen, is in some ways a harbinger of the grim cavalry battle in which the Trojans and their allies will participate in Book XI; Camilla, for her part, has affinities with the goddess Minerva (at least in her martial aspects). We might note that Aurora heralds both the arrival at Minerva's sacred locale and the opening of the book of Camilla.

${ }^{19}$ If it were indeed January when the voyage was made, the weather would indeed have been a consideration; one wonders, too, if the associations of that month with the god Janus were on the poet's mind (i.e., the backward glance to Troy, the forward to Italy).

${ }^{20} \mathrm{Cf}$. III $537 \mathrm{ff}$.

${ }^{21}$ On the sanctity of night and the tradition of incubatio rituals, see BOAs, H.: Aeneas' Arrival in Latium: Observations on Legends, History, Religion, Topography and Related Subjects in Vergil, Aeneid VII, 1-135. Amsterdam 1938. 1984,59

${ }^{22}$ For the facies used to describe the dream image see NEGRI, A.: Gli psiconimi in Virgilio. Roma

${ }^{23}$ See here EdGEwORTH, R.: The Colors of the Aeneid. New York 1992, 29ff., 54ff., 74ff.; Edgeworth notes that ater "is the first color term mentioned in the poem. The first three instances of color in the Aeneid are all instances of ater". 
is, on the first part of her journey in the heavens. Once again the context for the nocturnal epiphany involves war; Anchises' ghost advises that the weak and weary be left in Sicily, while the brave and stouthearted (V 729 fortissima corda) may be taken to Italy - where a war, after all, must be fought (V 730-731 ... gens dura atque aspera cultu / debellanda tibi Latio est). ${ }^{24}$ Once again, the context is one of a planned journey to Italy. In Book III, the mood was one of eager anticipation at the prospect of the long awaited landfall in Italy. In Book V, the atmosphere is fraught with anxiety and stress with respect to the abandonment of those who are incapable of proceeding to Hesperia. The moods are very different - the harbingers of war all the same..$^{25}$ There is a certain oppressive character to the narrative, in that landfall in Italy spells the imminent eruption of war and violence. Nautes - the old man whose name means "sailor" - urges that some travelers be left behind in Sicily; Anchises confirms the wisdom of the sailor's advice. In fine, it would have been better had the helmsman been among those who remained with Acestes. Night has once again been associated with war, and the present scene prepares us for the imminent Palinurus episode that will provide a framing crown to the narrative that commenced in Book III. Palinurus will not be left behind in Sicily, but he will meet his death in Italy.

The next mention of Night comes in quick succession, in the same sequence of Aeneas' dream vision. Anchises' ghost notes that midnight has come, and that the sun is pressing on his course:

iamque vale; torquet medios Nox umida cursus et me saevus equis Oriens adflavit anhelis.

V $738-739^{26}$

Appropriately enough in the context of a dream apparition, there is a marked emphasis on Night; this is the evening on which Aeneas' father offers the recommendation that some Trojans not finish the journey to Italy. ${ }^{27}$ In some ways this is an admission of failure; not all the exiles from Troy will survive all the way to Latium. When Night next descends, as it were, in an important sense she will preside over the doom of a Trojan who will survive to see Italy a second time - only to meet his death on its shores. ${ }^{28}$ And the conceit about the approach of the morning stands in contrast to the aforementioned underworld scene where the Sibyl admonished Aeneas that it

\footnotetext{
${ }^{24}$ On the exact nature of the facies of Anchises, see WiLliams, R.: P. Vergili Maronis Aeneidos Liber Quintus. Oxford 1960, ad 722: "the actual shade of Anchises is in Elysium... This is an apparition or vision."

${ }^{25}$ For Aeneas' taking of action only after the advice given by his father, and for the renewed theme of war, see MACK, S.: Patterns of Time in Vergil. Hamden, Connecticut 1978, 64-65; for the association of Anchises' advice with Jupiter, cf. HIGHET, G.: The Speeches in Vergil's Aeneid. Princeton 1972, 30.

${ }^{26}$ Cf. V 42 primo Oriente; Georgics I 249-250 (with MYNORS, R.: Virgil: Georgics. Oxford 1990, ad loc. for the identification of Oriens with the rising sun). The Oriens is "savage" (saevus) because it drives on the Night and separates the image of the father from his beloved son; one may also see an allusion to the four horses that symbolized the outbreak of war in Italy (especially if the sun is imagined as having a four-horse chariot).

${ }^{27}$ The shared detail about the "humid Night" (V 738, V 835) serves to link together the two passages; Palinurus faces a watery peril at the close of the book.

${ }^{28}$ It is possible that in Palinurus' two arrivals in Italy (the second fatal) there is something of a wry comment on the Orphic/Pythagorean concept of rebirth and renewal.
} 
was now past noon, and that Aeneas needed to hasten on his way to visit the shade of his father in Elysium.

It was almost midnight when Palinurus was visited by the god Somnus:

iamque fere mediam caeli Nox umida metam contigerat ...

V 835-836

This passage is the harbinger of Somnus' assault on Palinurus; the sequence of the loss of Aeneas' helmsman closes with the Trojan leader's ignorance of the circumstances of his sailor's death (V 870-871). The scene harks back to the near midnight hour of the departure for Italy; then, Palinurus was awake and alert as he investigated the stellar signs that marked the voyage west. That scene culminated in an omen of future war; in some sense, Palinurus is the first casualty of the war in Italy. ${ }^{29}$ Sleep has indeed brought a baleful dream to the helmsman of Aeneas' Trojan fleet. ${ }^{30}$

What had been foreshadowed, then, in no small part through the baleful portents of the stormy stars of Book III is now made reality; the serene sky of the first journey (III 518) has been replaced with the somewhat false serenity of the closing movement of Book V. ${ }^{31}$ For the second time we meet Palinurus in the time just before midnight - and in this instance, he will be a casualty of the war that draws ever nearer. The Palinurus episode that closes Book V straddles the midnight hour; it commences just before the middle of the night.

Of the four appearances of Night in the first half of Virgil's epic, the framing pair in Books III and V concerns Palinurus, the Trojan journey to Italy, and ultimately the sacrificial loss of the helmsman (as something of a proxy death for Aeneas). ${ }^{32}$ In both cases, the explicit temporal referent for the commencement of the episode is to the period just before midnight. The other two references to the goddess come in quick succession as part of the description of Anchises' ghostly visitation of his son, in connection with the planned departure from Sicily to Italy. These key nights of Books III and the close of Book V preface nighttime voyages to Italy; the night of the dream vision of Anchises comes before the nine days of feasting (V 762 Iamque dies epulata novem gens omnis) that mark in some sense not only the foundation of a new city in Sicily, but also the imminent loss of Palinurus - novemdiales that close a ring with those in memory of the anniversary of Anchises' death. ${ }^{33}$

Palinurus (as helmsman of the fleet) was a key figure in both departures for Italy; Anchises, for his part, both alive and dead proclaims the forthcoming war in

${ }^{29}$ That is, he is the Protesilaus of Virgil's epic; cf. the revelation of his ultimate fate at VI $355 \mathrm{ff}$., where the gens crudelis of 359 recalls the gens dura of $\mathrm{V} 730$.

${ }^{30} \mathrm{Cf}$. V 838-841.

${ }^{31}$ Cf. V 851-852 Aenean credam (quid enim)) fallacibus auris / et caeli totiens deceptus fraude sereni?; V, 871 o nimium caelo et pelage confise sereno.

${ }^{32}$ Below we shall consider the unique circumstance of the periphrastic reference to the "mother of Eumenides" at VI 250, as Aeneas makes his mysterious offerings before his descent into the underworld. As Horsfall notes ad loc., three of the four deities mentioned in that passage are identified periphrastically.

${ }^{33}$ Cf. V $64 \mathrm{ff}$. 
Italy (of which Palinurus will in some sense be the first victim). ${ }^{34}$ Aeneas will meet the shade of Palinurus in the underworld (VI 337-383), the first of three encounters with ghosts from his past (Dido and Deiphobus). After the triad of troubled and troubling memories is endured, the Sibyl echoes the ghost of Anchises in announcing that the night is rushing on in her swift course; where Aeneas' father had declared the passing of midnight, the Sibyl warns of the passing of noon. ${ }^{35}$ In Book V, the passage of night heralds the need for the ghost of Anchises to leave his son; in the underworld, the waning of the day drives on the son to visit the shade of his father in Elysium. Book V opens with an atmosphere that is heavy with the memory of the anniversary of the loss of Anchises (not to mention the tragedy of Dido); it closes with the loss of Palinurus. Both Palinurus and Anchises (together with Dido) are all revisited in Avernus: a neat composition of funerary and sepulchral images. We have full circle in the progress of the nocturnal epiphanies of the first half of the poem; Night has been associated closely with both war and sacrificial death.

There are four more named references to Night in the epic, thus providing a balance of references in the Odyssean and Iliadic halves of the poem. In Book VII, the two mentions of the goddess do not refer to actual nocturnal events; the same will be the case of the two subsequent references in Book XII. ${ }^{36}$ In the first half of the epic, the goddess was mentioned only in terms of her actual nocturnal course across the heavens; she was arguably merely a faint personification of the swift course of the night. In the books of war, as it were - the Iliadic half of the Aeneid - she will be mentioned in her personal, genealogical capacity as the mother of the hellish Furies; she will take her place as the mother of those powerful forces of fury and madness that wreak such havoc in the latter books of Virgil.

Night will now appear as the object of propitiatory offerings, and as the parent of avenging spirits of destruction and death. Night is linked closely with the commencement of war in Italy, and with the death of arguably the first Trojan casualty of the arrival in Hesperia. Not surprisingly, it will be the very daughter of Night who plays a major role in the outbreak of hostilities. The second tetrad of named references to the goddess, then, show her in something of a more personal and less merely temporal connection; again, as the war commences in Italy, we see the figure of Nox in her maternal capacity as the source of fury.

The scene is the first meal after the landing in Italy, ${ }^{37}$ the context is marked once again by portents. The celebrated fulfillment of the Harpy Celaeno's omen of

\footnotetext{
34 There is a certain curious arrangement of visions and revelations here; in Book III, Anchises predicted the coming of war, and in Book V, his shade advises that some Trojans not continue on the way to Italy. The helmsman who is princeps ante omnis (V 833) will, in fact, be the first to die, even if technically the war has not commenced.

35 "It seems bizarre in this context, but for Aeneas the ordered brightness of the upper world continues" (Austin, R.: P. Vergili Aeneidos Liber Sextus. Oxford 1977, ad loc.).

${ }^{36}$ Below we shall consider a further close parallel in the mentions of Nox, namely the references to Allecto and the Dira as daughters of Night. For the sibling affinity for the use of Fury-like avatars, see DYSOn, J.: King of the Wood: The Sacrificial Victor in Virgil's Aeneid. Norman, Oklahoma 2001, 128.

${ }^{37}$ VII 107ff., where see HorsfaLl, N.: Virgil: Aeneid 7. Leiden-Boston-Köln, 2000, ad loc.
} 
the "eating of the tables" is noted by Aeneas' son Iulus (VII 116-117) $;^{38}$ offerings are made at once by Aeneas to an array of immortals:

Sic deinde effatus frondenti tempora ramo

implicat et geniumque loci primamque deorum

Tellurem Nymphasque et adhuc ignota precatur

flumina, tum Noctem Noctisque orientiaque signa

Idaeumque Iovem Phrygiamque ex ordine matrem

invocat, et duplicis caelo Ereboque parentis.

VII $135-140$

And the prayer is "answered" at once by a triple clap of thunder; a rumor goes abroad among the Trojans that the day has come for the founding of the destined walls of a new home (VII 144-145 diditur hic subito Troiana per agmina rumor / advenisse diem quo debita moenia condant). ${ }^{39}$

The list of deities repays close study. ${ }^{40}$ The genius loci is followed at once by Earth as "first of the gods," and then by the nymphs, and the rivers that are as yet unknown. ${ }^{41}$ Night follows, and in dramatic fashion; the polyptoton of VII 138 Noctem Noctis draws attention and emphasis to the dark goddess. Idaean Jove and the "Phrygian Mother" (i.e., Cybele) are next in sequence (ex ordine); the queue of worthies ends with Venus and Anchises - parents in heaven and Erebus. ${ }^{42}$

"We do not know why the local nymphs should stand before Jupiter and the Magna Mater." ${ }^{43}$ The key to the apparent mystery is the identification of Jupiter as Idaean, and the reference to the great Trojan Mother goddess; in the final resolution of matters ethnic in Latium, the Italian will win out over the Trojan, and so the local deities are named first. Juxtaposed between the local world of Italy and the dead world of Troy is the mysterious figure of Nox and her stars, a night that in this case presages the forthcoming "second" death of Troy in Jupiter's announcement to Juno of the future destiny of Troy. ${ }^{44}$ This is the waning night of Troy, even as it is the birth of the

${ }^{38}$ The curse that Celaeno enjoins on the Trojans is that dira fames will come upon the Trojans before they gird their destined city with walls (III 256); the adjective serves in part to underscore the connection of the Harpies with the Furies/Dirae. Celaeno's name, we might note, evokes the night (on this point see further CARTER, M.: Celaeno. In VE I 250.)

${ }^{39}$ The scene is regrettably not discussed in SYSON, A.: Fama and Fiction in Vergil's Aeneid. Columbus, Ohio 2013. For the question of whether or not the thunder comes in a clear sky, see HORSFALL (n. 36) ad VII 141 (no, contra Servius). For possible associations of serenus and clarus, see PASCHALIS, M.: Virgil's Aeneid: Semantic Relations and Proper Names. Oxford 1997, 134.

${ }^{40}$ Tellurem is particularly interesting, given that in Hesiod (Theogony 184ff.) Earth is the mother of the Furies, contra the Virgilian version that owes much to tragedy (Aeschylus, Eumenides 321-323, etc.).

${ }^{41}$ With possible ominous reference to Juturna, as we shall consider below. For the significance of nymphs in the Virgilian landscape, cf. HARDIE, P.: Virgil's Aeneid: Cosmos and Imperium. Oxford 1986, 218-219, with reference to the Lucretian treatment of Fauns and Nymphs at De Rerum Natura IV 580ff. On the metaliterary aspects of Virgilian nymphs, see THOMAS, R.: Reading Virgil and His Texts: Studies in Intertextuality. Ann Arbor 1999, 132-135.

${ }^{42}$ For the attention paid by Aeneas to the veneration of gods both minor, local gods and the more powerful universal ones, see C. MACKIE, The Characterisation of Aeneas, Edinburgh: Scottish Academic Press, 1988, 146.

${ }^{43}$ Horsfall (n. 36) ad loc.

${ }^{44}$ XII 819ff., where see TARRANT, R.: Virgil: Aeneid XII. Cambridge 2012, ad loc. 
Rome that will be Italian and not Trojan. ${ }^{45}$ As the stars of Night rise, Idaean Jove, Cybele, and the "double parents" of the sacred union of Venus and Anchises fade and are obscured in the gloaming of an ever encroaching night. ${ }^{46}$ Aeneas is happy that the dira fames threatened by the Harpy has proven to be a trivial thing; his invocation on what will prove to be the eve of war has a tinge of irony in light of the ultimate suppression of Troy that will crown the Virgilian narrative of the conflict in Latium.

The present sacrifice to Night and other deities constitutes something of a parallel to the offerings made by Aeneas to the "mother of the Eumenides" and other immortals at VI 250ff.:

\section{Aeneas matri Eumenidum magnaeque sorori ense ferit, sterilemque tibi, Proserpina, vaccam; tum Stygio regi nocturnas incohat aras}

\section{250-252}

The commentators have exercised their ingenuity on the identity of the "great sister"; ${ }^{47}$ clearer is the maternal relationship of Night and the Furies. ${ }^{48}$ Ultimately, the reference to Nox in Book VII foreshadows the appearance of her daughter (the Fury Allecto) later in the book; she, of course, will be sent to earth at the behest of Juno. ${ }^{49}$ The recipients of offerings in the underworld were all chthonic deities (appropriately enough); from those infernal spirits but one has remained - the mother of the Eumenides, the goddess Nox. Offerings are made to Night in the underworld to ensure a safe descent (and presumed return); on Italian soil, sacrifices are performed to appease the gods and to ensure relative safety - for the announcement of war has by now been amply declared, not least by Anchises. Ascanius (and Aeneas) may be correct in the conclusion that the prophecy of Celaeno was harmless - but it is as if they have no idea (despite the warnings of Anchises et al.) of just how hazardous the future will be. ${ }^{50}$ The war in Italy is preceded by not one but two sacrifice rituals to Night; neither accomplishes the perhaps impossible task of staving off a war.

${ }^{45}$ "The stars are rising as he speaks" - FORDYCE, C.: P. Vergili Aeneidos Libri VII-VIII. Oxford
1977, ad loc.
${ }^{46}$ For the reference to Erebus (and not, say, Elysium), see HORSFALL (n. 36) ad VII 140 (recte) but the allusion is rather different all the same from the brightly lit mood of Elysium, especially so soon after the narrative of Aeneas' katabasis. Cf. WEST, M.: Hesiod: Theogony. Oxford 1966, ad 123 ("the region of darkness as opposed to the realm of light"). On the problem of Aeneas' "nostalgia" for Troy, see Wiltshire, S.: Public \& Private in Vergil's Aeneid. Amherst, Massachusetts 1989, 70-71. Here the reference carries with it something of the atmosphere of the grave; it conveys something of the spirit of death that broods over Troy.

${ }^{47}$ See especially HORSFALL (n. 10) ad loc.; the Servian interpretation is Earth. The oblique reference may well be to Juno as the great sister of Jupiter; see further here FRATANTUONO, L.: Nondum Proserpina Abstulerat: Persephone in the Aeneid. Revue des études anciennes 114.2 (2012) 423-434, esp. 428-429.

${ }^{48}$ Cf. WEST (n. 45) ad Theogony 123: "Night regularly occupies a high place in Greek cosmogonies."

${ }^{49}$ And so whether the magna soror is Earth or Juno is perhaps academic; in either case, Book VII will see the descent of the dread Fury to earth.

${ }^{50}$ In fairness, certainly there is relief at the revelation of the apparent meaning of the dira fames of which the Harpy warned - but in the final analysis, the offerings of Aeneas at the fateful meal will have associations both to the mother of Allecto and to the patron deities of the dead Troy - a catalogue of ominous references. 
From Night, Fury: ${ }^{51}$

'hunc mihi da proprium, virgo sata Nocte, laborem, hanc operam, ne noster honos infractave cedat

fama loco, neu conubiis ambire Latinum

Aeneadae possint Italosve obsidere finis.

VII 331-334

So Juno addresses the Fury Allecto as she prepares for a dramatic escalation of her actions against the Trojans: both the honor of the goddess and the relationship of the children of Aeneas to Latinus and the Italians are at stake. ${ }^{52}$ Indeed, the goddess' honor is virtually linked to the continuing sanctity and inviolate integrity of the Latins and Italians in the face of the de facto Trojan invasion.

Aeneas prayed to the Night and her rising stars - and in return, in effect he has received her daughter, the Fury who will help to instigate the war in Latium that had been predicted by Anchises. We might note, too, that the offerings to Night came in the wake of the apparent fulfillment of the prophecy of Celaeno regarding the socalled eating of the tables; the Harpies have affinities to the Furies/Erinyes. ${ }^{53}$ The portent of the "eating of the tables" would seem to have been fulfilled without any serious harm to the Trojans, indeed in an atmosphere of humor and quasi-comedy - but the real horror is yet to come for Aeneas and his men, and Allecto may well prove to be more deserving than Celaeno of the appellation maxima Furiarum. ${ }^{54}$

We might note, too, that the language of Juno's prayer is redolent with the spirit of Latin and Italian boundaries; the goddess prays that Allecto prevent the children of Aeneas from besieging the Italian borders. In this wish she will be successful; Troy will be suppressed and Italy ascendant. ${ }^{55}$ The ultimate disposition of affairs in Latium, however, does not preclude the apparent need for a bloody war - or for the deaths of either a Palinurus or a Turnus. Indeed, Allecto will in some ways be the agent that helps to ensure the victory of Juno; the Furies will be employed as avatars of the angry goddess in the nativity of what will be an Italian Rome. And once Juno's victory is assured, said Furies will be free to spread venom and violence elsewhere.

${ }^{51}$ On the significance of N/night to the end of Book XII (with particular reference to parallel treatments of Aurora and Sol), cf. PÖTSCHER, W.: Vergil und die göttlichen Mächte: Aspekte seiner Weltanschauung. Hildesheim 1977, 120-121. For the possible Ennian influence in the description of Allecto here, see GoldSCHMIDT, N.: Shaggy Crowns: Ennius' Annales and Virgil's Aeneid. Oxford 2013, 134-135.

${ }^{52}$ For parallels between Allecto and the Arethusa of Eclogues X, see PUTNAM, M.: Virgil's Epic Designs: Ekphrasis in the Aeneid. New Haven, Connecticut 1998, 106-107; cf. below on the depiction of Juturna in Aeneid XII. For consideration of the view that Juno's employment of Allecto signals an abandonment of any real hope of changing destiny, but rather a resolute determination to cause as much havoc as possible, see SYED, Y.: Vergil's Aeneid and the Roman Self: Subject and Nation in Literary Discourse. Ann Arbor 2005, 125.

${ }^{53}$ See further here PANOUSSI, V.: Vergil's Aeneid and Greek Tragedy: Ritual, Empire, and Intertext. Cambridge 2009, 84, 85, 89-90.

${ }^{54}$ On certain aspects of the parallels between Allecto and Celaeno, see NELIS, D.: Vergil's Aeneid and the Argonautica of Apollonius Rhodius. Leeds 2001, 303-304. The question of the identity of the Furiarum maxima was of course open to debate; cf. VI 605, where Megaera is a likely candidate for the appellation.

${ }^{55}$ With VII 333 ambire cf. the uses of the same verb at VI 550 and X 243, also with a sense of "bordering"; and note IV 283, of the idea of "hemming in" the angry Dido. 
Night was the mother of Allecto, and she also gave birth to the mysterious Dirae of Virgil's last book (XII 845ff.):

\begin{abstract}
dicuntur geminae pestes cognomine Dirae, quas et Tartaream Nox intempesta Megaeram uno eodemque tulit partu, paribusque revinxit serpentum spiris ventosasque addidit alas.
\end{abstract}

The Dirae are more or less synonymous with the Furies; ${ }^{56}$ throughout the epic these denizens of hell are depicted as being prone to avenging of all manner of sin (real or perceived). ${ }^{57}$ Night is their mother, and here the goddess is labeled intempesta, that is, "stormy" or even "unhealthy". 58

Interestingly, the Virgilian Dirae appear at a moment in the narrative where we find Juno at last reconciled to fate and indeed happy (XII 841 laetata), namely on the occasion of the climactic revelation that the future Rome will be Italian and not Trojan. ${ }^{59}$ The Virgilian Dirae play an important role in the death of Turnus, a doom that must be endured notwithstanding the divine agreement about Troy and Rome that remains unannounced either to Turnus or Aeneas. ${ }^{60}$ Jupiter sends one of the two Dirae down to earth, specifically as a messenger or omen to Turnus' sister Juturna. ${ }^{61}$ Like a Parthian or Cydonian shot of a poisoned arrow (XII 856-858), the Dira descends to earth - the Dira who, we are reminded, is the daughter of Night:

$$
\text { talis se sata Nocte tulit terrasque petivit. }
$$

XII 860

This is the final reference to the goddess Nox in the epic; her offspring the Dira has been sent down by Jupiter on the express mission of providing an omen to Juturna - the

\footnotetext{
${ }^{56} \mathrm{Cf}$. IV 473 and 610, both times in Didonian contexts; VIII 701, where they are prominent on the shield of Aeneas in the depiction of Actium.

${ }^{57}$ For useful summary of their depiction in Virgil, see PANOUSSI, V.: Furies. In VE II 514-515.

${ }^{58}$ Cf. III 587, and Georgics I 247, also of the night; X 184, of the Graviscae who live in malarial conditions (on which see HARRISON, S.: Vergil: Aeneid 10. Oxford 1991, ad loc.).

${ }^{59}$ In some sense Virgil thus closes a ring with the initial appeal of Juno to Allecto for help in preventing the Aeneadae from assailing the borders of Italy; now that the security of Ausonia is assured, there is no need for continued resistance by either Juturna or Turnus, and so the Dira can be sent to drive off the local goddess from the field of battle, and to terrorize the hero whose resistance has become otiose. In an important sense, the agents of Fury - the Dirae and perhaps Allecto - will be involved in driving away Juturna and in seeking to frighten Turnus - but they will possess Aeneas, as fury and madness depart from those whose cause has proven victorious (albeit a victory that is hidden from the mortal actors in the drama, and even from the Venus who is conspicuously absent from the final movements of the epic).

${ }^{60}$ For useful consideration of such matters as the apparent Virgilian "syncretic fusion of Roman aves prodigiales and Greek Vogeldämonen", see BARCHIESI, A.: Homeric Effects in Vergil's Narrative. Princeton 2015, 101-103 (translation and updated version of the author's 1984 La traccia del modello). U1timately, one can also consider the Furor impius of I 294-296; any future chaining of madness is beyond the chronological scope of the epic.

${ }^{61}$ XII 853-854 harum unam celerem dimisit ab aethere summo / Iuppiter inque omen Iuturnae occurrere iussit. Juturna is a figure that straddles the mortal and divine planes; she is dismissed from the scene immediately after the reconciliation of the goddess Juno - after the divine settlement of affairs in Latium, there is no reason for an immortal like Juturna to remain on the scene of the mortal postlude to heaven's colloquy.
} 
point being that the river goddess must leave the battlefield and refrain from further assistance to her doomed brother. ${ }^{62}$

The Dira descends, and the omen she offers to the Italian nymph is the terrorizing of her brother Turnus. Juturna is one of the local deities of Latium; she was the most favored of the Latin nymphs, indeed the glory of the rivers, as Juno had addressed her in fawning language:

\section{'nympha, decus fluviorum, animo gratissima nostro, scis ut te cunctis unam, quaecumque Latinae}

magnanimi Iovis ingratum ascendere cubile
XII 142-144

The purpose of the omen is to drive Juturna from the battlefield; the last goddess, as it were, must be banished from the cause of defending the doomed Rutulian Turnus and that goddess is a sacred, local heroine. The form of the omen is the avian metamorphosis of the Dira into a bird of ill omen that will torment Turnus. The commentators have noted the apparent oddity of having the mission to Juturna be conflated with the terrorizing of her brother, ${ }^{63}$ the point at least in part is to underscore all too clearly to the sister how her brother is beyond salvation. ${ }^{64}$ The Jovian mission of the Dira is related to the reconciliation of Juno and the agreement about the future status of Latium; again, the point throughout is that Juturna and Turnus are no longer needed - Juno has won her victory.

The Dira's attack on Turnus is not dissimilar to Somnus' assault on Palinurus (V 838ff.) - another figure who was all too otiose in the employment economy of the epic. ${ }^{65}$ There, Sleep descended to Aeneas' flagship to urge Palinurus to take his rest; after his unsuccessful attempt and resort to violence, the god returns to the upper air as a winged creature (V 861 ipse volans tenuis se sustulit ales ad auras). ${ }^{66}$ The omen succeeds in frightening off Juturna from the cause of assisting her brother; she retreats into the river that is her sacred abode, though not without a memorable lament (XII 885-886). ${ }^{67}$ Turnus, for his part, is overcome with fear (XII 867-868) - but the real effect of the Dira is still to come.

${ }^{62}$ And if the Dira in question is indeed Allecto, then we can discern a balance between the appearances of the Fury in Book VII to Turnus, and her manifestation now; on the former occasion, she came as an agent of Juno, and in the guise of her priestess Calybe (whose very name connotes "hiding" and concealment); now, with Juno happy and at rest, she comes as a messenger of Jupiter.

${ }^{63}$ Cf. especially TARRANT (n. 43) ad XII 865-868.

${ }^{64}$ For how Juturna is sundered from mortality (most poignantly from her brother), see DI CESARE, M.: The Altar and the City: A Reading of Vergil's Aneid. New York 1974, 227-231. Juturna is a local goddess of Latium; though her side is victorious ultimately in the Latin war, she must still endure the loss of her all too mortal sibling.

${ }^{65}$ Indeed, Palinurus was unnecessary in the wake of Neptune's agreement to ensure a safe passage for the Trojans from Sicily to Cumae; in both Book V and Book XII, a Saturnian god is prominent in the final movements.

${ }^{66}$ Cf. Homer, Iliad XIV 290ff., where Sleep undergoes a metamorphosis into a singing bird, perhaps a sort of owl (see further JANKO, R.: The Iliad: A Commentary, Volume IV, Books 13-16. Cambridge 1992, ad loc.).

${ }^{67}$ The lament of Juturna has received sympathetic commentary; see in particular BARCHIESI, A.: Il lament di Giuturna. Materiali e discussion per l'analisi dei testi classici 1 (1978) 99-121. For insightful 
Aeneas appears on the scene in the immediate aftermath of the entrance of the Dira and the departure of the goddess; there will be no clash between Trojan hero and Italian river nymph (XII 887ff.). ${ }^{68}$ Turnus admits his fear - but he identifies its source as being decidedly non-mortal (and non-Trojan) in a memorable retort: non me tua fervida terrent / dicta, ferox; di me terrent et Iuppiter hostis (XII 894-895). ${ }^{69}$ The language that Turnus employs to describe Aeneas and his words - fervida and ferox - look forward to the description of Aeneas as furiis accensus at XII 946.

Turnus seeks to lift up a huge rock, a veritable boulder that scarcely twelve men of normal strength could carry (XII 896ff.). ${ }^{70}$ His intention is to attack Aeneas with this saxum antiquum ingens - but soon enough he realizes that something is very wrong indeed. He cannot throw the stone with sufficient force to strike Aeneas; he does not recognize his own self. ${ }^{71}$ In a celebrated simile - the last direct simile in the epic - he is like a man in a dream: ${ }^{72}$

ac velut in somnis, oculos ubi languida pressit

nocte quies, nequiquam avidos extendere cursus

velle videmur et in mediis conatibus aegri

succidimus; non lingua valet, non corpore notae

sufficiunt vires nec vox aut verba sequuntur:

sic Turno, quacumque viam virtute petivit,

successum dea dira negat.

XII 908-914

The Dira returns to the narrative, as she essentially imposes a waking sleep on the Rutulian hero. ${ }^{73}$ The Dira is associated here with the ability to employ sleep and

remarks on the nature of Juturna's retreat into her waters, see OBBINK, D.: Vergil's De pietate: From Ehoiae to Allegory in Vergil, Philodemus, and Ovid. In ARMSTRONG, D. ET AL. (eds.): Vergil, Philodemus, and the Augustans. Austin, Texas 2004, 175-209, esp. 181. We might note that Palinurus was alone on deck when Somnus assaulted him, in contrast to Turnus, who enjoys the protection and assistance of his divine sister for as long as possible.

${ }^{68} \mathrm{Cf}$. how Aeneas also never meets the Volscian heroine Camilla in battle. Camilla, for her part, has significant affinities with both Allecto and the Dira (who may, after all, be one and the same); on this see further Fratantuono, L.: Dirarum ab sede dearum: Virgil's Fury Allecto, the Dirae, and Jupiter's Parthian Defeat. Bollettino di studi latini 41.2 (2011) 522-530.

${ }^{69}$ This sentiment hints at Turnus' realization that the bird of ill omen was sent by Jupiter. For commentary on how "Virgil delays Turnus' reaction to the apparition of the Dira," with consideration of the question of the non-negotiable status of the fate of Turnus, and the possibility of the hero's punishment for his sins, see Horsfall, N.: A Companion to the Study of Virgil. Leiden-Boston-Köln 2000, 211.

${ }^{70}$ Cf. the "inverse simile" (so TARRANT [n. 43] ad loc.) at XII 921-923, with its description of a siege engine.

${ }^{71}$ XII 903-904 sed neque currentem se nec cognoscit euntem/ tollentemve manu saxumve immane moventem.

${ }^{72}$ The "phantom Aeneas" sequence of X $633 \mathrm{ff}$. is something of a prelude to this climactic dream
image.
${ }^{73}$ TARRANT (n. 43) ad loc. rightly compares VII, 324 dirarum ab sede dearum, of Allecto as she
is summoned by Juno. On the vexed question of the identity of the Dirae, with argument for the inter-
pretation that the Virgilian Dirae are Allecto, Tisiphone, and Megaera, see MACKIE, C.: Vergil's Dirae,
South Italy, and Etruria. Phoenix 46.4 (1992) 352-361 (who notes the nocturnal parentage of Euripides'
Lyssa at Hercules Furens $822-823$, a passage that has significance for the Virgilian depiction of Allecto; 
somnolence as a weapon to work her will; Turnus is awake, and yet his abilities are as constrained and constricted as are those of a man deeply submerged in slumber. ${ }^{74}$ Palinurus struggled to remain awake in the face of the tempting, beguiling efforts of Somnus; the god was finally forced to act more directly and indeed violently in working his soporific will. Both Somnus and the Dira in some sense succeed in putting their respective quarries to sleep, and Turnus' waking dream foreshadows his eternal sleep in death. ${ }^{75}$ The present scene offers a clear case of divine intervention; the Dira takes away both Turnus' physical strength, and his power of voice. The Dira is explicitly given credit for the failure of Turnus to exercise his virtus (X 913-914). The stone that Turnus tried to hurl at Aeneas had been a boundary marker (XII 896-898); in light of the final disposition of ethnic affairs in Italy that Jupiter and Juno had discussed, there is no need of a terminus; all will be one, and that one will be Ausonian and not Trojan. $^{76}$

Allecto, for her part, also attacked Turnus in the realm of dreams (VII 416ff.); ${ }^{77}$ indeed, as scholars have noted, Turnus' Allecto dream is one of the rare instances in the epic where a character is able to converse with a figure while submerged in sleep. $^{78}$ The fury disguises herself as Calybe, an aged priestess of Juno; it is only after the revelation of the angry goddess' true appearance and identity that Turnus is roused from his deep slumber by fear (VII 458 olli somnum ingens rumpit pavor). ${ }^{79}$ The message of the fury is simple: she has come from the dread seat of the sisters (the sorority of the Furies, as it were), and in her hand is war and annihilation. ${ }^{80}$ When Turnus awakes from this dream, he is seething with anger and memorably compared to a boiling vessel of water (VII 462-466). ${ }^{81}$ Whether or not the Dira that

see further here KöNIG, A.: Die Aeneis und die griechische Tragödie: Studien zur imitatio-Technik Vergilis. Berlin 1970, 123-136).

${ }^{74}$ The Dira takes away Turnus' power of speech; for how Allecto had once used Turnus as a viertbale mouthpiece of her will, see POWELL, A.: Virgil the Partisan: A Study in the Re-Integration of the Classics. Swansea 2008, 165.

${ }^{75}$ On this "letzte Traum" of the epic, see STEINER, H.: Der Traum in der Aeneis. Bern 1952, 72-75.

${ }^{76}$ Cf. further here FLETCHER, K.: Finding Italy: Travel, Colonization, and Nation in Vergil's Aeneid. Ann Arbor 2014, 248-249.

${ }^{77}$ For the difficult question of how much of the assault on Turnus (and Amata, for that matter) is divinely inspired, and how much a mere awakening of a latent rage that is already present, see e.g. JENKYNS, R.: Virgil's Experience: Nature and History, Times, Names, and Places. Oxford 1998, 584.

${ }^{78}$ On this sequence see especially Kragelund, P.: Dream and Prediction in the Aeneid, Copenhagen 1976, 63-70; STEINER (n. 74) 1952, 62-66. It was about midnight when Allecto's dream visitation came to Turnus (VII 414 mediam quietem). For associations between this scene and the nocturnal assault on Palinurus, see ReED, J.: Virgil's Gaze: Nation and Poetry in the Aeneid. Princeton 2007, 61-63.

${ }^{79}$ For perceptive commentary on this scene, see SMITH, R.: The Primacy of Vision in Virgil's Aeneid. Austin, Texas 2005, 36-38. For how Turnus is shaken with fear in the wake of the visitations of Allecto and the Dira, see HENRY, E.: The Vigour of Prophecy: A Study of Virgil's Aeneid. Carbondale, Illinois 1989,120 . The only other instance of dialogue in dreams is the encounter of Aeneas with Hector at II $268 \mathrm{ff}$.

${ }^{80}$ VII 454-455 respice ad haec: adsum dirarum ab sede sororum, / bella manu letumque gero.

${ }^{81}$ For Virgil's characterization of Turnus in this dream sequence, see CAIRNS, F.: Virgil's Augustan Epic. Cambridge 1989, 69-70; for comparison with Aeneas, cf. the reflections of HORNSBY, R.: Patterns of Action in the Aeneid: A Study of Vergil's Epic Similes. Iowa City 1970, 100-103. For connections between the present scene and the dreamlike vision of Aeneas with Tiberinus, see GEORGE, E.: Aeneid VIII and the Aitia of Callimachus. Leiden 1974, 94-95. 
attacks Turnus at the end of the epic is Allecto, there is a framing element to the ruin of Turnus; in Book VII the Rutulian is attacked in a dream, and now, in Book XII, he is reduced to quasi-somnambulism, a waking dream that will lead to his death. Night is, after all, the realm of dreams; the darkness that descends in the closing movements of the epic is both real (evening is drawing near) and metaphorical. And the fury of the encroaching darkness of the end of the epic will be reserved for Aeneas. ${ }^{82}$

Both Palinurus and Turnus die within the chronological framework of the $A e$ neid; the cases of Aeneas and Juturna are rather different. In the former instance, the Trojan hero is initially unaware of the fate of his helmsman; it is only after his descent to the underworld that he learns the story of what happened on the fateful night of the departure from Sicily. ${ }^{83}$ Juturna is aware of her brother's impending disaster, though she is not witness to the final scenes of his ruin; she chooses instead to bury herself deep in the river that is sacred to her. Palinurus dies as something of a proxy sacrifice for Aeneas; Aeneas survives the timeline of Virgil's epic, though traditionally he would meet the end of his mortality, at least, in the waters of another river - the Numicus. ${ }^{84}$ The watery loss of Palinurus is transformed into the eternal memory the hero is granted at the place that bears his name (VI 378-383); Aeneas, for his part, undergoes both death and apotheosis. ${ }^{85}$ In some respects we may compare Aeneas (the would-be protector of Palinurus) and Juturna; both will meet their "ends" in a river, and both are destined to be local gods of central Italy. ${ }^{86}$

Somnus' attack on Palinurus did not prevent the Trojan navigator from reaching Italy; death, however, followed at once upon his landing. Turnus, too, dies in Italy - and in the haunting final description of the Rutulian before he is struck by Aeneas' missile weapon, he is said to be looking at his men, the nearby city - and the poet notes that he cannot see his chariot or his sister (XII 915-918). ${ }^{87}$ Both Turnus and his sister are agents of Junonian fury and the will of the goddess; ${ }^{88}$ with the release of Juno from her anger and wrath, there is something of an abandonment of her avatars.

${ }^{82} \mathrm{Cf}$. Allecto's name, with its connotations of ceaseless activity; there is no final quelling of her anger in the narrative of the epic (the chaining of Furor is envisaged and not realized). See further here JOSEPH, T.: Allecto. In VE I 54-55.

${ }^{83}$ Aeneas is not made aware at any point of the intervention of Somnus in his guise as Phorbas.

${ }^{84}$ Cf. VII 150; 242; 797; Livy, Ab Urbe Condita I 2. 6 (with OGILVIE, R.: A Commentary on Livy, Books 1-5. Oxford 1965 [second edition 1970], ad loc.); Ovid, Metamorphoses XIV, $600-608$ (with MYERS, K.: Ovid: Metamorphoses Book XIV. Cambridge 2009, ad loc.). For a convenient account of the site, see TILLY, B.: Vergil's Latium. Oxford 1947, 66-82.

${ }^{85}$ See further JONES, P.: Numicus. In VE II 920.

${ }^{86}$ On the association of Juturna with the Numicus, see MCKAY, A.: Vergil's Italy. Greenwich, Connecticut 1970, 157; O'HarA, J.: Death and the Optimistic Prophecy in Vergil's Aeneid. Princeton 1990, 114-116 (with consideration of the idea that immortality is not always a boon).

${ }^{87}$ With the detail about Turnus' chariot cf. the detail at I 17 hic currus fuit, of the favored status of Juno's Carthage.

${ }^{88}$ For the semantic relations of their names (cf. Saturnia), see PASCHALIS (n. 38) 56-57. For consideration of the theory that the name connects most especially to an Etruscan term for "ruler" (with implications that Turnus is a "bad king"), see O'HARA, J.: True Names: Vergil and the Alexandrian Tradition of Etymological Wordplay. Ann Arbor 1996, 110, 185; cf. DUQUE, A.: La onomastica de Virgilio y la antigüedad preitálica, Volumen I. Salamanca 1949, 88-89. 
The recipient of the spirit of wrath and dire anger that had once infected Turnus is Aeneas; as he stands over the fallen Turnus, Virgil explicitly describes him as "set on fire by fury" ${ }^{\prime 89}$ or, perhaps better, by the Furies: ${ }^{90}$

... furiis accensus et ira

terribilis

XII 946-947

The fury of Juno has been inherited by Aeneas; ${ }^{91}$ Turnus, for his part, has been rather freed of the frenzy and madness that had possessed him from the time of Allecto's nocturnal assault. We might compare here the end of Book XI, where Turnus was furens (XI 901); the context there was the aftermath of Camilla's death (a death that would be marked with the same verse that describes Turnus'). ${ }^{92}$ Night approaches as the drama of Book XI draws to a close (XI 913-914); Virgil does not specify the time of day at which Turnus dies, though the "last day" of the epic is a long one, and one can reasonably conclude that both Camilla and Turnus died as the day was waning. ${ }^{93}$

${ }^{89}$ With accensus cf. the aforementioned V 719 Talibus incensus dictis senioris amici, of Aeneas in the wake of Nautes' advice about leaving behind some of the Trojans in Sicily. Incensus also appears in the epic of Coroebus (II 343), and of Euryalus (IX 342-343); accensus occurs at IV 203 of Iarbas after the reception of the rumor about Aeneas and Dido (an interesting comparandum in light of the question of Lavinia); most significantly, Juno is accensa at I 29 (near the opening of the epic) - rather a close here, then, to the ring of fury that encircles the epic. Elsewhere in the poem, accensa appears a striking two times in one verse of Lavinia at VII 75; also of Dido (IV 364; 697); Camilla (XI 709). Note too XII 9 accenso Turno; the entire epic may be framed by the transference of Juno's burning wrath to Aeneas, but the fire of her mortal avatar Turnus is also handed over, and accensus of both Turnus and Aeneas serves to draw together Virgil's last book.

${ }^{90} \mathrm{Cf}$. here the analysis of Putnam, M.: The Humanness of Heroes: Studies in the Conclusion of Virgil's Aeneid. Amsterdam 2011, 104. Note the sober commentary on Aeneas' emotional and mental state of TARRANT (n. 43) ad loc.: "undeniably disturbing". For consideration of furor as a major theme in the epic, note ADLER, E.: Vergil's Empire: Political Thought in the Aeneid. Lanham, Maryland 2003, $77 \mathrm{ff}$., with detailed consideration of the Juno-Aeolus scene from Book I and Lucretian antecedents. We might note that the Harpies were personifications of tempestuous winds and the blasts of storms; cf. above on the offerings to Night after the seemingly harmless resolution of the Harpy's threat, and the imminent appearance of Allecto, etc. Cf. also HorSFALL (n. 5) ad III 246 infelix vates. And Celaeno, of course, is the maxima Furiarum (III 252), at least in her own estimation. The harmless enough "eating of the tables" in Latium may well be something of an "end of labors" (VII 117-118 ea vox audita laborum / prima tulit fidem), but greater labors and more dread Furies await the Trojans. On how the "end of labors" is actually transformed into the "first cause of labors" (prima causa laborum) in war at VII 481ff., see KüHN, W.: Götterszenen bei Vergil. Heidelberg 1971, 109-110.

${ }_{91}$ Aeneas is the last furious figure in the epic; for how the concept of furor is applied most often in the poem to Dido, see FARron, S.: Vergil's Aeneid: A Poem of Grief \& Love. Leiden - New York - Köln 1993, 137-138. The final appearances of both Dido and Turnus stand in contrast to that of the Trojan hero.

${ }^{92}$ XI 831 = XII 952. Turnus is also described as being driven by fury near the start of Book XII (101 his agitur furiis); also at XII 668 et furiis agitatus amor et conscia virtus; the poet dramatically emphasizes the fury of Turnus in the prolegomena to the final scene of Aeneas' rage.

${ }^{93}$ See here MANDRA (n. 8) 171-172, with reference to XII 113-115, the announcement of the final morning of the poem. Aurora had been associated with the first Trojan arrival in Italy, and Aurora is named in the opening of Book XI, the only book of the epic that commences with a dawn formula; Virgil wishes thereby to associate Camilla (the heroine of Book XI) with the traditions surrounding Marcus Furius Camillus, who had connections with Aurora (on this see DuMÉZIL, G.: Camillus: A Study of IndoEuropean Religion as Roman History. Berkeley 1980). On the significance of Aurora in the Virgilian 
In an important sense, this is the final appearance in the epic of the daughters of the goddess Night; here the action of the Furies comes not in dream and the world of nocturnal slumber, but in the all too bright light of day. Aeneas has become something of a living Fury of Pallas, as the madness and rage of the grim Erinyes is reborn in Italy. ${ }^{94}$ It was not yet midnight when the Trojans first made ready to depart for what would be their first landfall in Italy; Night had not yet been driven by the Hours half the distance across her nocturnal course. As the epic draws to a close, Aeneas is possessed by the daughters of Night; ablaze (accensus) with the fury of the children of the dark goddess, he slays Turnus. The Sibyl had warned Aeneas in the underworld that the night was rushing on as Aeneas wept and the hours passed (VI 539 nox ruit, Aenea; nos flendo ducimus horas); by the close of the poem, Night and her children have taken full possession of the scene, as the life of Turnus flees to the shadows. ${ }^{95}$

Lee Fratantuono

Professor of Classics

Ohio Wesleyan University

Delaware, Ohio, U.S.A.

depiction of Italy, see FRATANTUONO, L.: Iamque rubescebat: Aurora in the Aeneid. Eos 100.2 (2013) 297-315

${ }^{94}$ On the image of the Erinys Pallantis, see RENGer, C.: Aeneas und Turnus: Analyse einer Feindschaft. Frankfurt am Main 1985, 96-98; cf. SCHENK, P.: Die Gestalt des Turnus in Vergils Aeneis. Königstein 1984, 358-359.

${ }_{95}^{95}$ If the Erinys Pallantis has taken its vengeance on Turnus for his actions in Book X, then Aeneas is the embodiment of that Fury; what neither hero realizes in the final, bloody moments of the epic is that the new settlement in Italy will be decidedly Italian and not Trojan - notwithstanding the apparent victory of the furious Aeneas. 